\title{
М.Л. Кирилюк
}

\section{МЕНОПАУЗА: СУЧАСНІ УЯВЛЕННЯ ПРО БЕЗПЕКУ ТА ЕФЕКТИВНІСТЬ ЛІКУВАННЯ}

Украӥнський науково-практичний центр ендокринної хірургії, трансплантації ендокринних органів і тканин МОЗ України, Київ

Визначення. Механізм розвитку та чинники, що йому сприяють. Менопауза - це цілковите припинення менструацій. Менопауза настає внаслідок зниження секреції оваріальних гормонів естрогенів і прогестерону, що відбувається після вичерпання наявної кількості оваріальних фолікулів. Природну менопаузу діагностують через 12 місяців після настання аменореї, не пов'язаного 3 патологічними причинами (хірургічне втручання кастрація, хіміотерапія, іонізуюче опромінення тощо). 3 початку періоду переходу до менопаузи тривалість менструальних циклів змінюється, вони стають нерегулярними, і у відповідь на зниження концентрації оваріальних гормонів підвищується концентрація фолікулостимулюючого гормону (ФСГ) (рис. 1). У міру наближення до менопаузи відзначається «випадіння» менструальних циклів, i врешті вони припиняються, як і овуляція. У деяких жінок наявність аменореї впродовж трьох місяців або середня тривалість циклу понад 42 дні $\epsilon$ прогностичним чинником менопаузи, що настає. Період переходу до менопаузи часто супроводжується додатковим впливом старіння організму та труднощами соціальної адаптації.

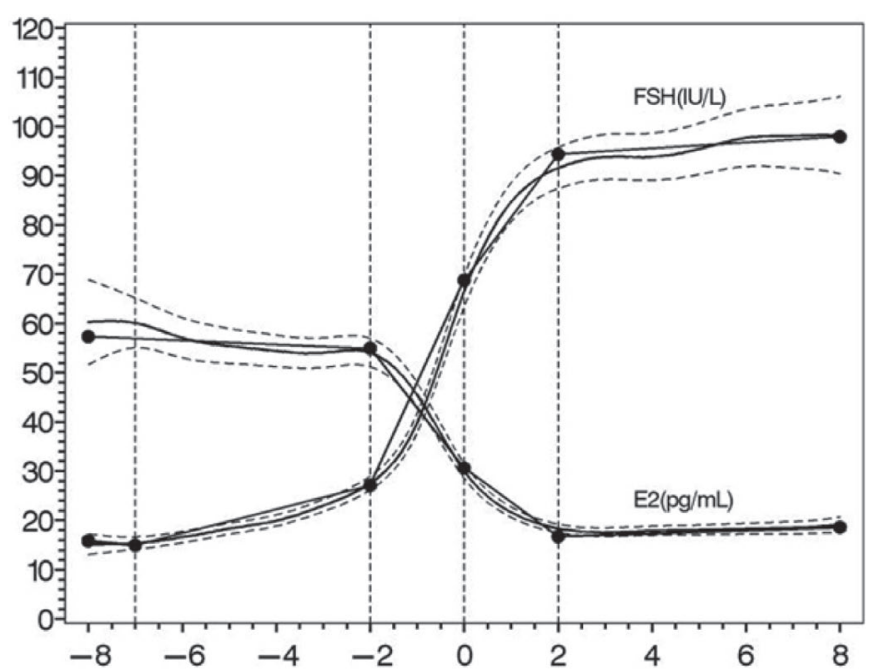

Puc. 1. Концентрація ФСГ та естрадіолу у крові жінок впродовж 8 років перед останнім менструальним циклом і 8 років після нього ( $n=1215)$ (95\% довірчий інтервал, вісь X-роки) [11].
Використовують декілька термінів для опису подій, які відбуваються під час переходу до менопаузи. У моделі, розробленій на Симпозіумі зі стадій репродуктивного старіння 2001 року та модифікованій 2012 року (Stages of Reproductive Aging Workshop - STRAW), виділено 10 стадій старіння репродуктивної системи (табл. 1), розподілених у свою чергу на репродуктивні стадії, що характеризуються регулярними менструальними циклами, стадії переходу до менопаузи з нерегулярними менструальними циклами та високими рівнями ФСГ та стадії постменопаузи, що починаються з останнього менструального періоду та тривають до кінця життя. Існують значні індивідуальні коливання, що включають пропускання окремих стадій і перехід від однієї стадії до іншої у зворотному порядку. У цілому у моделі STRAW пременопауза відповідає репродуктивним стадіям, перименопауза - стадіям переходу до менопаузи, а постменопауза починається з моменту останньої менструації.

Перехід до менопаузи зазвичай починається у жінок у віці 45-50 років і може тривати декілька років, найчастіше - 4-5 років. Останній менструальний цикл, як правило, буває у віці 40-58 років. Припинення менструацій у віці до 40 років вважається передчасним.

Результати популяційних досліджень свідчать, що куріння тютюну та низьке соціально-економічне положення асоціюються із передчасним останнім менструальним періодом. Іншими чинниками, які можуть впливати на вік припинення менструацій, $\epsilon$ :

- вік початку менструацій;

- кількість пологів в анамнезі;

- використання пероральних контрацептивів у минулому;

- індекс маси тіла;

- етнічна приналежність;

- родинний анамнез.

За результатами великих досліджень із проведенням опитування, вік останнього менструального циклу різниться у різних країнах. Наприклад, в Італії, Ірані, Словенії та США такий середній вік складає 50-51 рік, у Кореї, Лівані, Сінгапурі, Греції, Марокко, Мексиці, Тайвані та Туреччині - 47-50 років. 
중

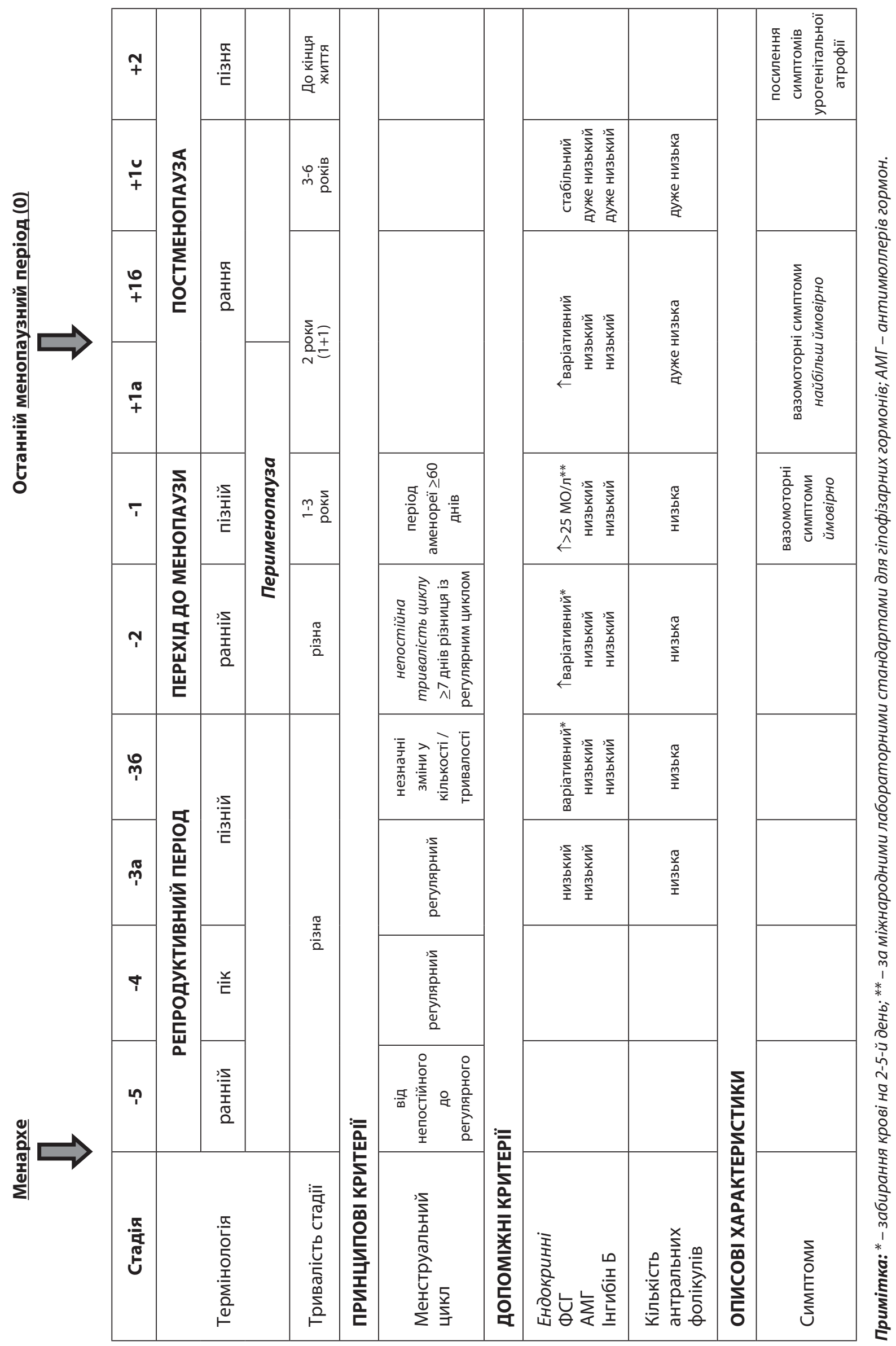




\section{ЛЕКЦії}

Клінічні прояви. Із менопаузою пов'язують багато клінічних проявів, провідними 3 яких $\epsilon$ вазомоторні симптоми (табл. 2).

Епізоди вазомоторної дисфункції проявляються у вигляді раптового відчуття жару, зазвичай у ділянках грудної клітки, шиї та обличчя, що часто супроводжуються потовиділенням, серцебиттям і відчуттям тривоги. Ці епізоди описують як «припливи» («hot flush» або «hot flash») i «нічну пітливість». Термін «hot flush» означає відчуття тепла, а «hot flash» - підвищену пітливість, яка іноді переходить в озноб, утім, ці терміни у медичній літературі часто використовують як взаємозамінні. Епізоди вазомоторних порушень різняться за частотою, тривалістю та тяжкістю, іноді можуть повторюватись і зазвичай тривають щонайбільше 5 хвилин. Вони можуть бути спровокованими перебуванням у теплому приміщенні, вживанням гарячої їжі або напоїв, стресовими ситуаціями. Частота та інтенсивність їх мають виражені індивідуальні розбіжності - від легких поодиноких до багаторазових, виснажливих. Із припливами також пов'язано порушення сну та нічну пітливість. Ці симптоми мають понад половину жінок у період менопаузи. Деяким жінкам такі епізоди настільки заважають у повсякденному житті, що вони звертаються по лікарську допомогу. Хоча у багатьох жінок більшість симптомів зникають впродовж декількох місяців, в інших вони можуть тривати декілька років після останнього менструального циклу. Близько 29\% 60-річних жінок скаржаться на постійні припливи.

Механізми, що спричинюють вазомоторні симптоми, остаточно не з'ясовано. Одна з теорій полягає у тому, що зниження концентрації естрогенів обумовлює зменшення концентрації ендорфінів у гіпоталамусі, що призводить до підвищеного вивільнення норадреналіну (норепінефрину) та серотоніну. Ці медіатори знижують поріг терморегуляторного ядра та провокують неадекватну втрату тепла.

Урогенітальні проблеми, такі як сухість, свербіж у піхві та диспареунія, обумовлено фізіологічною реакцією на зниження концентрації естрогенів та андрогенів. До таких реакцій належать зменшення піхвового кровообігу та кількості секрету, тканинні зміни в органі та зміни рН піхвової рідини від кислого до нейтрального. Також із переходом до менопаузи асоціюються такі додаткові симптоми, як відчуття тривоги, депресія, мінливість настрою, нетримання та підтікання сечі, порушення сну, когнітивні зміни, соматичні скарги та сексуальна дисфункція. За допомогою факторного аналізу вста- новлено, що стан менопаузи частіше пов'язано $з$ вазомоторними, а не з психічними або фізичними симптомами.

На сухість піхви скаржаться приблизно третина жінок у менопаузний період. Крім того, у жінок у менопаузі частіше відзначаються порушення сну, іноді внаслідок вазомоторних симптомів. Приблизно 40-60\% жінок потерпають від порушення сну під час менопаузної та постменопаузної стадій. У деяких, але не в усіх, дослідженнях скарги на нетримання та підтікання сечі пов'язують з менопаузою. Жінки повідомляли про зниження статевої чутливості, лібідо та частоти статевих актів у менопаузний період, а депресію та сухість піхви визнають надійними прогностичними чинниками зниження статевого потягу.

Складно розмежувати клінічні ознаки, пов'язані із власне менопаузним переходом і з процесами старіння у цілому. Інтерпретація результатів дослідження менопаузних дисфункцій вимагає обережності з огляду на розбіжності у термінології та обмеження методів дослідження. Розроблено безліч методів оцінки менопаузних симптомів, але лише окремі з них $\epsilon$ стандартизованими, валідованими та надійними. Шкала клімактеричних симптомів Грина (Green climacteric scale), індекс Куппермана (Kupperman index) та анкета якості життя у менопаузі (menopause-specific quality of life questionnaire) $є$ прикладами найчастіше використовуваних балових систем оцінки менопаузних симптомів.

Зв'язок між переходом до менопаузи та мінливістю настрою, розвитком психічних розладів або загальним психічним здоров'ям встановлено у дослідженнях Pennsylvania Ovarian Aging Study (2004), Study of Women's health Across the Nation (SWAN) (2007) та Eindhoven Perimenopausal Osteoporosis Study (1998).

Дослідження на великих когортах надають корисну інформацію про перехід до менопаузи. Проте на індивідуальні випадки можуть впливати багато додаткових чинників. Не викликає сумніву значення етнічних і культурних чинників, але які саме чинники (біологічні або соціокультурні) справляють найбільший вплив, наразі не встановлено. Генетичні особливості, характер дієти, наявність пологів в анамнезі, маса тіла, фізична активність і вплив чинників довкілля різняться залежно від етнічного походження та культури та цілком можуть справляти вплив на перехід до менопаузи, як це відбувається відносно інших фаз репродуктивного періоду та життя у цілому. До того ж сприйняття та опис симптомів жінками різняться залежно від 


\section{Вазомоторні:}

- $\quad$ гарячі припливи або припливи жару

- холодні кінцівки

- пітливість

- тремор, серцебиття

- прискорений пульс

- головний біль

Соматичні:

- слабкість

- втомлюваність

- судоми

- біль у суглобах

- зниження апетиту

- нудота, блювота

- біль у шлунку

- закріп

- ожиріння

- зменшення розмірів і в'ялість молочних залоз

- потреба вночі вставати до туалету (никтурія)

Психічні:

- мінливість настрою

- напруженість

- дратівливість

- безсоння

- депресія

- негативна самооцінка

- відчуття поколювання

- неможливість концентрації уваги

Урогінекологічні:

- сухість піхви, що утруднює статевий акт і нерідко сприяє приєднанню інфекції

- піхвова атрофія

- почастішання сечовипускання, никтурія, схильність до інфекцій сечового міхура

Сексуальні:

- зниження статевого потягу (лібідо) від легкого ступеня до цілковитої втрати бажання сексу

Ортопедичні:

- системний остеопороз

- підвищений ризик переломів, надто шийки стегнової кістки

Ознаки, пов'язані з віковим дефіцитом гормону росту:

- сухість очей

- глибокі зморшки

- тонке, сухе волосся, зниження росту волосся, дифузна алопеція

- зміни статури зі зменшенням зросту

- $\quad$ сухість, зниження еластичності та стоншення шкіри

- зморшкуваті нігті

- ослаблення пам'яті та когнітивних функцій

- погані якість і глибина сну

Ознаки, пов'язані з віковим дефіцитом тиреоїдни гормонів:

- сухе, шорстке, позбавлене блиску, рідке волосся

- одутле обличчя

- байдужий погляд

- потовщення повік

- товсті губи

- суха, шорстка шкіра

- збільшення маси тіла, згладженість силуету тіла

- холодні кінцівки

- повільність, втома зранку та під час відпочинку

- депресія

- слабкі пам'ять та когнітивні функції 


\section{ЛЕКЦії}

культурного та освітнього рівня. Деякі жінки можуть інтерпретувати вазомоторний симптом як відчуття жару, інші описують його як запаморочення або інше відчуття.

У перименопаузі може відбуватися швидке збільшення маси тіла, що відзначається приблизно у $60 \%$ жінок. За даними Дослідження здоров'я жінок (Healthy Women's Study), у перші три роки після менопаузи маса тіла збільшується у середньому на 2,3 кг (у 20\% випадків - на 4,5 кг і більше), а через 8 років - на 5,5 кг. Один із механізмів впливу статевих стероїдів на жирову тканину - це пряма регуляція активності ліпопротеїнліпази. Естрогени стимулюють ліпопротеїнліпазу у жировій тканині стегон і сідниць, де активність даного ферменту вища, ніж в абдомінальній ділянці, пригнічують синтез нейропептиду Y (на тлі дефіциту естрогенів концентрацію останнього збільшено, що сприяє підвищенню апетиту та гіперфагії). Крім того, вони діють безпосередньо на вентромедіальну ділянку гіпоталамуса, тим самим пригнічуючи апетит, регулюють продукцію лептину за принципом позитивного зворотного зв'язку, пригнічують синтез тирозингідроксилази, що бере участь у синтезі катехоламінів, збільшують щільність а2-адренорецепторів на адипоцитах. Із настанням менопаузи активність ліпопротеїнліпази знижується, і периферичні адипоцити зменшуються у розмірах, тобто відбувається відносний перерозподіл жиру. Прогестерон також впливає на жирову тканину через конкуренцію 3 глюкокортикоїдами за їх рецептори на адипоцитах, перешкоджаючи дії глюкокортикоїдів на жирову тканину у пізню лютеїнову фазу менструального циклу.

Ведення та лікування. 2011 року у Римі відбувся 13-й Всесвітній конгрес із менопаузи. На ньому було представлено оновлену версію рекомендацій Міжнародного товариства менопаузи (International Menopause Society, IMS) із застосування замісної гормональної терапії (3Г) у постменопаузний період і стратегій збереження здоров'я у середньому віці. На багато питань щодо переходу до менопаузи та його впливу на здоров'я відповідей наразі немає. Найбільш раціональним $\epsilon$ індивідуальний підхід до ведення жінок із менопаузними симптомами. Оновлену версію рекомендацій IMS було представлено у момент, коли атмосфера навкруги питання про застосування 3Г у постменопаузний період стала зваженішою та сприятливою після отримання детальних результатів великого дослідження Women's Health Initiative (WHI) із застосування кон'югованого естрогену у монотерапіії або у комбінації з медроксипрогестерону ацетатом, що довели важливість віку початку терапії та добрий профіль безпеки ЗГ за умов застосування у жінок віком до 60 років. I саме на вік і ранній початок застосування 3ГТ звертається увага в останніх рекомендаціях провідних фахівців. У терапії лікарськими засобами для купірування менопаузних симптомів важливо враховувати характеристики їх ефективності та безпеки.

Гормонотерапія. У рекомендаціях IMS під терміном «замісна гормональна терапія» розуміють лікування 3 використанням естрогенів, прогестагенів, комбінацій препаратів, андрогенів і тибілону.

Впродовж багатьох років естрогени використовували як допоміжну гормонотерапію за наявності менопаузних симптомів. Наразі їх застосування $\epsilon$ найбільш ефективним методом лікування вазомоторної дисфункції та урогенітальної атрофії у більшості жінок.

Сьогодні ці гормони вже не рекомендують застосовувати для профілактики хронічних станів та їх ускладнень (IXC, інсульт, гострий коронарний синдром, колоректальний рак), хоча вони $\epsilon$ ефективними як засіб профілактики остеопорозу.

Застосування естрогенів для лікування припливів досліджували у багатьох рандомізованих контрольованих дослідженнях. Більшість із цих досліджень проведено у США або країнах Західної Європи, тому у них оцінювали ти види естрогенів, що найчастіше використовуються у цих країнах, зокрема естрадіол і кон'юговані естрогени.

Препарати естрогенів випускають у різних лікарських формах, найчастіше для перорального, трансдермального або інтравагінального застосування. Жінкам зі збереженою маткою естрогени призначають за схемою комбінованої, або «врівноважлювальної» терапії, коли естроген використовують у комбінації з прогестагеном. Даний метод застосовують з метою запобігання розвитку гіперплазії та раку ендометрію. Комбіновану терапію можна проводити циклами, впродовж яких окремі компоненти схеми приймають у певні дні місяця або безперервно, коли обидва гормони приймаються щоденно.

Слід пам'ятати, що, крім очікуваної дії на ендометрій, прогестагени можуть різнитися за своїми можливими несприятливими ефектами на метаболізм або асоційованим ризиком раку молочної залози (РМЗ) за умов поєднання з терапією естрогенами впродовж тривалого часу.

Існують гестагени з кардіопротекторним ефектом. Зокрема, 2010-2011 роками застосовувався синтетичний аналог природного прогестерону 


\section{ЛЕКЦії}

дидрогестерон, який не лише впливає на концентрацію тригліцеридів, але й знижує рівень загального холестерину у середньому на 7\% за рік, ліпопротеїнів низької щільності (ЛПНЩ) - на 15\% і підвищує вміст ліпопротеїнів високої щільності (ЛПВЩ) на 12\% за рік. Дидрогестерон входить до складу комбінованого естроген-гестагенного препарату. За результатами порівняльного аналізу 3 медичною базою даних UK General Practice Research Database $(n=69412)$, використання поєднання дидрогестерону 3 естрадіолом впродовж від декількох місяців до декількох років не підвищувало ризик серцево-судинних захворювань (ССЗ) порівняно з відсутністю ЗП.

Жінки, у яких відсутня матка, можуть приймати естроген без прогестагену (схема без врівноваження ефектів). Дози залежать від конкретного складу препарату, але у сучасних рекомендаціях пропонують застосовувати мінімальну ефективну дозу впродовж максимально короткого часу, необхідного для зменшення вираженості симптомів. Дози, нижчі від тих, які застосовувалися у практиці раніше, можуть достатньою мірою зменшувати симптоми та підтримувати якість життя у багатьох жінок.

Рекомендується також періодично намагатися знижувати дозу або відміняти лікування естрогенами для мінімізації ймовірності розвитку побічних явищ, але ідеальну схему таких заходів наразі не розроблено. Ефект естрогенів зберігається впродовж 1-2 років після припинення лікування, проте потім слабшає, про що свідчать результати Дослідження здоров'я медичних сестер (Nurses' Health Study, або Framingham Nurses' Health Study, 1994). Крім того, для багатьох жінок припинення терапії естрогенами викликає певні труднощі, адже може відбуватися повторна поява симптомів.

У цілому причин для обов'язкових обмежень тривалості 3ГТ немає. Рішення про продовження або припинення терапії мають приймати добре інформована пацієнтка та її лікар залежно від мети лікування та об'єктивної оцінки користі та ризику на даний момент. ЗГ слід призначати індивідуально та добирати з урахуванням симптомів і необхідності профілактики, а також індивідуального та родинного анамнезу, результатів відповідних досліджень, уподобань та очікувань жінки.

Не слід проводити ЗГТ без чітких показань до її застосування, тобто за відсутності значних симптомів недостатності естрогенів.

Жінки, у яких спонтанна або ятрогенна менопауза настає у віці до 45, а надто - до 40 років, мають підвищений ризик СС3 та остеопорозу, а також вищий ризик розвитку афективних розладів і деменції. $\in$ свідчення, що тривала терапія естрогенами, розпочата з часу настання менопаузи, може справляти кардіопротекторну дію через підвищення рівня ЛПВЩ, зниження - ЛПНЩ, посилення вазодилатації, підвищення рівня NO, індукцію генів NO-синтетази, зменшення хронічного запалення за рахунок зниження синтезу молекул адгезії судинного ендотелію 1-го типу (VCAM-1), продукції чинника некрозу пухлин а (ЧНП-а), зниження рівня фібриногену, посилення пригнічення фібринолізу через зниження активності інгібітору активатора плазміногену 1 (PAl-1). ЗГ може пом'якшувати симптоми менопаузи та зберігати щільність кісткової тканини у таких жінок, і її застосування рекомендовано продовжувати щонайменше до досягнення середнього віку настання менопаузи.

За результатами Кокранівського мета-аналізу рандомізованих контрольованих досліджень встановлено, що у жінок із відповідними симптомами, які лікувалися різними препаратами естрогенів для перорального застосування, частота припливів знижувалася на 75\% (на 2,6 епізоду на добу). Зменшення тяжкості припливів було дещо більшим у жінок, яких лікували за схемою з врівноваженням ефекту естрогенів. Застосування естрадіолу у трансдермальній лікарській формі знижувало частоту припливів на 3,2 епізоду на добу незалежно від схеми лікування - 3 урівноваженням ефектів естрогенів або без нього. Порівняння ефективності препаратів різних естрогенів у паралельних групах (кон'югований естроген порівнювали з пероральним або трансдермальним) продемонструвало зниження числа та тяжкості припливів в усіх групах без помітних розбіжностей між групами (табл. 3).

Побічні ефекти естрогенів добре вивчено. У ході випробувань короткочасного лікування естрогенами встановлено, що найчастішими побічними ефектами $\epsilon$ болючість молочних залоз і маткові кровотечі. До інших належать нудота та блювота, головний біль, зміна маси тіла, запаморочення, венозні тромбоемболічні та серцево-судинні події, шкірні висипи та свербіж, холецистит і порушення функції печінки. У жінок, які приймають естрогени, відзначається «огрубіння» молочних залоз, що призводить до підвищення числа патологічних осередків, виявлених за даними мамографії.

Результати рандомізованого контрольованого дослідження «ніціатива в ім'я здоров'я жінок» (Women's Health Initiative, WHI, застосування кон'югованого естрогену у монотерапії або у комбінації 3 медроксипрогестерону ацетатом) продемонстрували, що на тлі обох схем лікування підвищується 


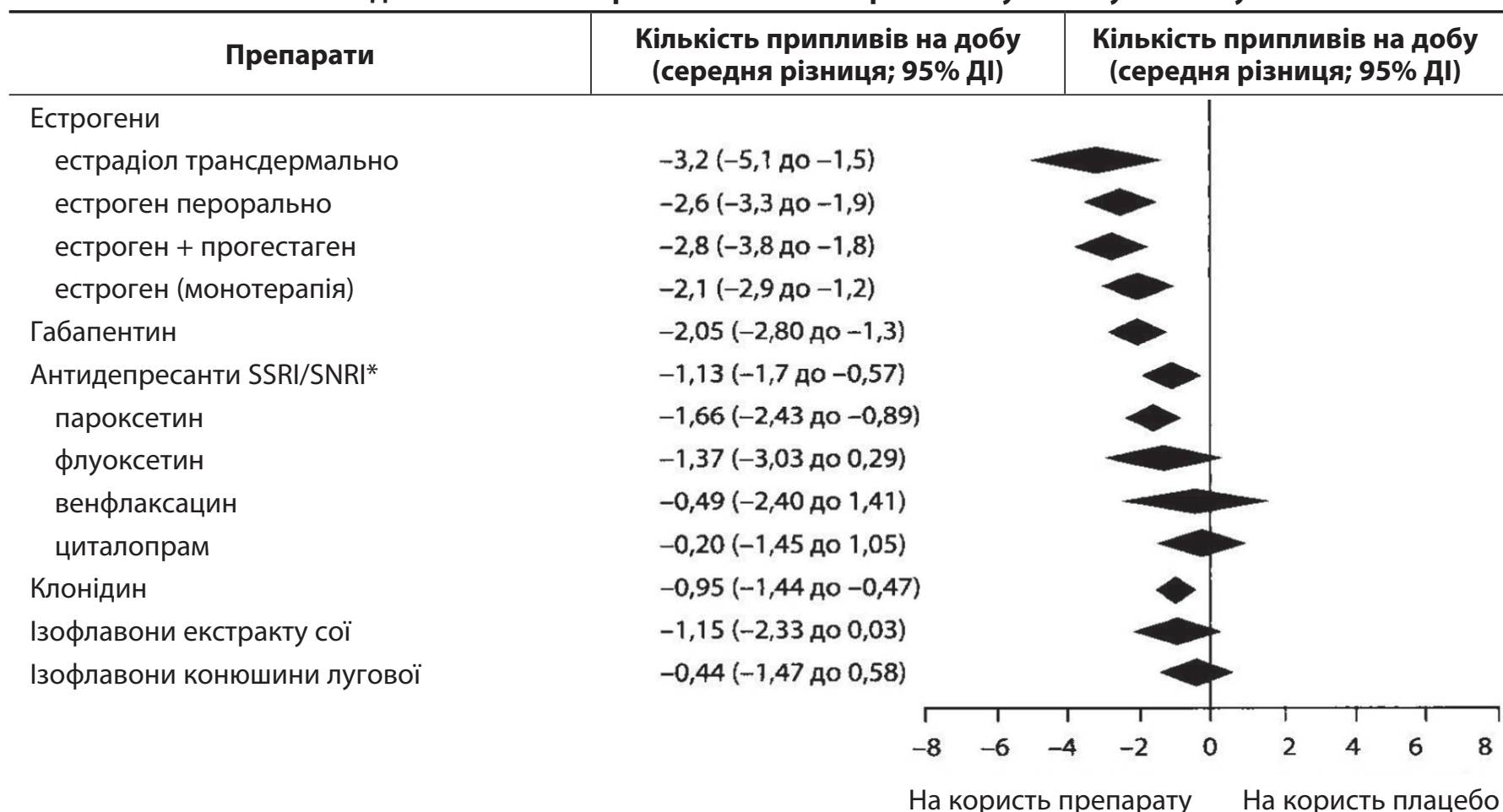

Примітка: *-SSRI-селективні інгібітори зворотного захоплення серотоніну, SSNI - інгібітори зворотного захоплення серотоніну та норадреналіну.

ризик інсульту та венозних тромбоемболій. Ризик IXC та інвазійного РМЗ підвищено у жінок, які отримували лікування кон'югованим естрогеном і медроксипрогестерону ацетатом, але не у тих, хто отримував кон'югований естроген у монотерапії. Вторинний аналіз даних WHI показав, що для жінок, які розпочинають гормонотерапію впродовж 10 років із часу настання менопаузи, ризик розвитку IXC $\epsilon$ меншим порівняно з тими, хто розпочав лікування пізніше. Естрогени не слід призначати жінкам із СС3, наявністю в анамнезі тромбоемболічних подій, із раком молочної залози або матки та захворюваннями печінки.

У невеликій кількості досліджень прогестагенів або прогестерону описано ефективність монотерапії даними препаратами щодо припливів, але ці результати $\epsilon$ суперечливими та не остаточними. $\epsilon$ повідомлення про результати порівняння використання комбінацій тестостерону та естрогену 3 монотерапією естрогеном. В одному випробуванні не було виявлено жодних розбіжностей для цих схем відносно тяжкості припливів. За результатами оцінки ефекту тіболону, синтетичного стероїду 3 прогестагенним, андрогенним та естрогенним ефектами, було виявлено зниження вираженості припливів і зменшення суми балів за шкалою Куп- пермана, але результати інших досліджень не підтвердили цих даних. Найчастішими побічними ефектами тіболону є маткові кровотечі, біль у різних ділянках тіла, у тому числі головний, збільшення маси тіла.

Жінкам, які приймають 3ГТ, слід не менше від 1 разу на рік обстежуватись у гінеколога з обговоренням способу життя та розробкою стратегії профілактики або пом'якшення перебігу хронічних захворювань, а також консультуватися із суміжними фахівцями за необхідності. Показань до частішого мамографічного обстеження або скринінгового аналізу мазків із шийки матки на даний час немає.

Негормональні засоби. Побоювання щодо побічних ефектів естрогенів, які виникли на підставі результатів дослідження WHI, опублікованих 2002 року, стали причиною підвищення уваги до негормональних засобів зменшення вираженості симптомів менопаузи. До цих засобів належать тамоксифен, аналог ү-аміномасляної кислоти габапентин, селективні інгібітори зворотного захоплення серотоніну (selective serotonin reuptake inhibitor SSRI) антидепресанти пароксетин, флуоксетин, циталопрам, вераліприд, моклобемід, інгібітор зворотного захоплення серотоніну та норепінефрину 
(serotonin norepinephrine reuptake inhibitor - SNRI) венлафаксин, сертралін, агоніст центральних а-адренергічних рецепторів клонідин (клонітидин), метилдопа, балергал петард (табл. 4).

Узгоджених доказів ефективності допоміжних препаратів у зниженні тяжкості та частоти припливів або нічної пітливості немає. За даними короткочасних випробувань, селективні інгібітори зворотного захоплення серотоніну та норадреналіну, а також габапентин ефективно зменшують частоту вазомоторних проявів. $\epsilon$ припущення, що припливи пов'язано з надмірним навантаженням сайтів серотонінових рецепторів у гіпоталамусі, які потім блокуються SSRI та SNRI. Для деяких жінок лікування наявної у них депресії може підвищити стерпність припливів. Клонідин може зменшувати вираженість припливів через зниження реактивності периферичних судин.

Засоби лікування, що не входять до призначень лікаря. Інтерпретація результатів дослідження застосування засобів лікування, що не входять до лікарських призначень, часто ускладнюється розмаїттям компонентів і використовуваних доз. Побічні ефекти, надто віддалені, вивчено не настільки добре, як такі рецептурних препаратів.

Такі назви, як «біоідентичні» або «природні» гормони, та їх реклама не мають наукових підстав. Так звані «природні», але синтезовані людиною гормони можуть міститись у «біоідентичних» препаратах у комбінаціях і дозах, які ніколи не вивчались у публічних обгрунтованих клінічних дослідженнях. Естрадіол, естрон або естріол звичайно отримують із рослинного ямсу, і вони мають бути ідентичними естрогенам яєчників. Дані про ефективність та безпеку тривалої терапії будь-яким із цих препаратів відсутні, і ризик, пов'язаний з їх застосуванням, також невідомий.

Фітоестрогени $\epsilon$ сполуками рослинного походження, що можуть зв'язуватися з естрогеновими рецепторами та проявляти слабку естрогенну або

Негормональні засоби для лікування вазомоторних симптомів у менопаузі

Таблиця 4

\begin{tabular}{|c|c|c|c|}
\hline 3aci6 & Доза, мг/добу & Ефективність, \% & Вибіркові потенційні побічні ефекти \\
\hline Габепентин & $100-200 \times 3$ рази на добу & Поліпшення на 17-30\% & $\begin{array}{l}\text { Сонливість, втомлюваність, нудота, } \\
\text { блювота, запаморочення }\end{array}$ \\
\hline \multicolumn{4}{|l|}{ SSRI/SNRI } \\
\hline Пароксетин & $\begin{array}{l}10-20 \text { і } 12,5-25 \\
\text { контрольованого вивільнення }\end{array}$ & Поліпшення на 25-30\% & $\begin{array}{l}\text { Головний біль, нудота, сонливість, } \\
\text { безсоння }\end{array}$ \\
\hline Флуоксетин & $20-30$ & Поліпшення на 25\% & Нудота та сухість у роті \\
\hline Циталопрам & $20-30$ & Поліпшення & Нудота та сухість у роті \\
\hline Сертралін & $50-100$ & Поліпшення & $\begin{array}{l}\text { Головний біль, нудота, сонливість, } \\
\text { сухість у роті та запаморочення }\end{array}$ \\
\hline Венлафаксин & $\begin{array}{l}\text { 37,5-150 пролонгованого } \\
\text { вивільнення }\end{array}$ & Поліпшення на 10-35\% & $\begin{array}{l}\text { Сухість у роті, нудота, зниження } \\
\text { апетиту, закрепи і безсоння }\end{array}$ \\
\hline Вераліприд & 100 & Поліпшення на 45\% & Мастодинія та галакторея \\
\hline Моклобемід & $150-300$ & Повідомлень немає & Сонливість \\
\hline \multicolumn{4}{|c|}{ Агоністи центральних а-адренорецепторів } \\
\hline Клонітидин & $\begin{array}{l}\text { Внутрішньо }(0,025-0,075) \\
2 \text { рази на добу. } \\
\text { Трансдермально 0,1 }\end{array}$ & Поліпшення на 13-26\% & $\begin{array}{l}\text { Сухість у роті, нудота, закрепи, } \\
\text { безсоння, сонливість, подразнення } \\
\text { шкіри за трансдермального } \\
\text { застосування }\end{array}$ \\
\hline Метилдопа & $375-1125$ & Поліпшення & Сухість у роті, нудота та втомлюваність \\
\hline Белергал ретард & $\begin{array}{l}\text { По } 1 \text { таблетці } 2 \text { рази на добу } \\
\text { (0,6 ерготаміну } \\
40 \text { фенобарбіталу, } \\
\text { 0,2 лівообертаючих } \\
\text { алкалоїдів) }\end{array}$ & Різниця відсутня & $\begin{array}{l}\text { Сухість у роті, запаморочення, } \\
\text { сонливість }\end{array}$ \\
\hline
\end{tabular}


антиестрогенну активність. У плацебоконтрольованих дослідженнях застосування ізофлавоноїдів екстракту сої, що містять переважно даїдзеїн, геністеїн та їх глюкокон'югати, відзначено змішаний ефект на припливи. Лише деякі дослідження засвідчили сприятливий вплив сої на частоту та вираженість припливів. Ізофлавоноїди конюшини лугової, що містять геністеїн, даїдзеїн, формононетин і біоканин, у плацебоконтрольованих дослідженнях не впливали на частоту та тяжкість, припливів. Фітоестрогени хмелю та льону у вигляді екстракту або форм для місцевого застосування також не продемонстрували позитивного ефекту. Китайські трави, олія енотери (Oenothera), фосфоліпідні ліпосоми та екстракт квіткового пилку також увійшли до цього переліку.

Клініцистам слід орієнтуватися на вірогідні джерела для отримання інформації щодо потенційних користі або шкоди окремих засобів (зокрема, таку інформацію надає Управління з харчових добавок при Національних інститутах здоров'я США). Так, наприклад, із тривалим застосуванням «біоідентичних» гормональних засобів, що містять естрогени, може бути пов'язано розвиток патології ендометрію. Препарат із клопогона китицеподібного (циміцифуга - Cimicifuga racemosa) $\epsilon$ рослинним засобом із можливим естрогенним ефектом. Відомо, що він не знижує частоти припливів, але асоціюється з ураженням печінки.

Остеопатичні маніпуляції, рефлексотерапія, акупунктура, магнітотерапія та вправи з аеробіки не справляють жодного позитивного ефекту щодо лікування припливів порівняно з плацебо.

Терапія симптомів, не пов'язаних із вазомоторними порушеннями. Лікування включає модифікацію способу життя (соціалізація, фізична та розумова активність) і медикаментозну терапію.

Основні рекомендації:

- боротьба з ожирінням (профілактика станів, пов'язаних із синдромом інсулінорезистентності, цукровим діабетом 2-го типу);

- дотримання принципів здорового харчування (декілька порцій овочів і фруктів на день, вживання харчової клітковини, риби двічі на тиждень, обмеження вживання жирів, солі, добова порція алкоголю має не перевищувати 20 г для жінок);

- відмова від куріння тютюну;

- регулярна фізична активність.

Регулярна фізична активність знижує рівень кардіоваскулярної та загальної смертності. У фізично активних жінок ліпшими $\epsilon$ обмін речовин, координація, м'язовий тонус, когнітивні функції та якість життя, а кардіальні події, інсульти, переломи, РМЗ і рак товстої кишки трапляються значно рідше. Користь від фізичних вправ суттєво перевищує їх імовірні несприятливі наслідки. Натомість надмірна активність може завдати шкоди.

Остеопороз. Метою лікування остеопорозу $\epsilon$ запобігання переломам. Для добору терапії слід виходити зі співвідношення ефективності, ризиків (безпеки) та вартості. Врахування співвідношення вартість/ефективність має сенс для жінок із підвищеним ризиком переломів. Поріг відносного ризику переломів $\epsilon$ специфічним для окремих країн і залежить від системи охорони здоров'я. Поріг втручання для призначення терапії може грунтуватися на 10-річній імовірності переломів.

\section{Гормональна терапія}

ЗГТ $\epsilon$ ефективною у профілактиці втрати кісткової тканини, пов'язаної з настанням менопаузи або вторинною аменореєю. Вона знижує частоту всіх переломів, пов'язаних з остеопорозом, у т.ч. переломів хребців і стегнової кітки, навіть у популяції жінок без високого ризику переломів.

ЗГТ можна розглядати як один із видів терапії першого ряду для профілактики та лікування остеопорозу у жінок у постменопаузі, молодших за 60 років, із високим ризиком переломів.

Доведено, що захисна дія 3ГТ на мінеральну щільність кісткової тканини втрачається із непередбачуваною швидкістю після припинення терапії, хоча певний ступінь захисту від переломів може і зберігатися. Пацієнткам групи високого ризику переломів може знадобитися додаткове лікування препаратами $з$ доведеними властивостями збереження кісткової тканини.

За умов продовження 3ГТ у жінок після 60 років лише з метою профілактики переломів слід враховувати можливі побічні ефекти, які можуть розвинутися на тлі певних доз і схем ЗГТ, і розглядати можливості застосування інших, перевірених методів лікування.

Розпочинати 3Г після 60 років лише з метою попередження переломів не рекомендується!

\section{Негормональна терапія}

Кальчій і вітамін D:

- рекомендоване щоденне вживання кальцію 3 їжею для жінок у постменопаузі складає 10001200 мг; добавки, що містять кальцій у кількості, яка перевищує рекомендоване вживання (загальне вживання), можуть несприятливо впливати на ССС;

- рекомендоване вживання вітаміну D з їжею у постменопаузний період складає 800-1000 Мод; біофосфонати: 
- біофосфонати $\epsilon$ потужними інгібіторами резорбції кісток і знижують швидкість ремоделювання кісток із доведеною ефективністю у профілактиці переломів хребців і стегнової кістки;

- біофосфонати справляють сприятливу дію на тлі деяких онкологічних захворювань і перешкоджають метастазуванню РМЗ у кісткову тканину.

Шкіра, хрящова тканина та інші сполучні тканини. ЗГТ сприятливо впливає на стан сполучної тканини, шкіри, суглобів і міжхребцевих дисків.

Шкіра, сонна артерія та міжхребчеві диски. Естрогени позитивно впливають на метаболізм сполучної тканини в усьому організмі. Після менопаузи у дермі відбувається втрата сполучної тканини, темпи якої на тлі застосування естрогенів у деяких випадках значно уповільнюються. Подібні зміни сполучної тканини відбуваються і у стінках артерій, стоншуються і міжхребцеві диски. Терапія естрогенами може запобігти цьому процесові.

Суглобові хрящі. Виражене переважання поліартикулярного остеоартриту та, зокрема, збільшення частоти розвитку остеоартриту у жінок після менопаузи свідчить про важливість жіночих статевих гормонів для гомеостазу хрящів. Вчасний початок терапії естрогенами / селективними модуляторами естрогенових рецепторів може запобігти втраті кісткової та хрящової тканини, що супроводжує менопаузу, через прямі та опосередковані механізми.

Можливі серйозні небажані ефекти 3ГТ. Дослідження ризиків, пов'язаних із застосуванням гормонів у постменопаузі, фокусувалися переважно на РМЗ та раку ендометрію, венозній тромбоемболії (легеневій або тромбозі глибоких вен), інсульті та коронарних захворюваннях.

Серцево-судинна система. Менопаузу можна вважати чинником ризику розвитку IXC у жінок через потенційний вплив згасання функції яєчників на стан ССС, артеріальний тиск (АT) і різні метаболічні параметри (толерантність до глюкози, ліпідний профіль). ССЗ $є$ основною причиною захворюваності та смерті жінок у період менопаузи. Стратегія профілактики (крім контролю харчування та відмови від куріння) має бути спрямованою на контроль АТ, маси тіла, метаболізму глюкози та ліпідів. Стенокардія у жінок частіше перебігає без обструкції коронарних артерій, але у разі інфаркту прогноз для жінок $\epsilon$ значно гіршим, ніж для чоловіків.

Гормональна терапія у постменопаузі та ІБС. Більшість результатів передклінічних та обсер- ваційних досліджень підтверджують користь 3Г у зниженні ризику розвитку IXC, адже естрогени сприятливо впливають на різні метаболічні чинники ризику IXC. Встановлено також, що із застосуванням ЗГТ пов'язано зниження ризику розвитку цукрового діабету 2-го типу.

Результати масштабних рандомізованих та обсерваційних досліджень свідчать про важливу роль віку у вирішенні питання про початок застосування 3П. $€$ докази, що терапія естрогенами може справляти кардіопротекторну дію, якщо ії розпочати у пре- або перименопаузі та продовжувати протягом тривалого часу (концепція «вікна терапевтичних можливостей»).

У жінок віком до 60 років, у яких симптоми менопаузи з'явилися нещодавно та немає ознак СС3, початок ЗГТ не викликає ранніх несприятливих наслідків і може знизити захворюваність і смертність від IXC. Рішення про продовження ЗГ у таких жінок має прийматися на підставі загальної оцінки співвідношення користь/ризик.

Сприятливу дію ЗГТ на коронарні судини відзначено лише у тих жінок, у яких менопауза розпочалася менше ніж 10 років тому. Початок ЗП у віці понад 60 років, а також у жінок із тривалістю менопаузи понад 10 років може збільшувати ризик розвитку кардіоваскулярних захворювань переважно у перші 2 роки застосування. Тому проводити ЗГТ у віці понад 60 років виключно з метою первинної профілактики IXC не рекомендовано!

У рутинній практиці не рекомендовано розпочинати 3ГТ у жінок похилого віку з IXC, які приймають кардіопрепарати за стандартними терапевтичними схемами.

Вплив 3Гт на інсульт. Ризик розвитку інсульту корелює з віком - в осіб віком до 60 років він виникає зрідка. ЗГ може збільшувати цей ризик, надто після 60 років.

Після настання менопаузи не відзначається значних змін ризику інсульту залежно від віку або часу настання менопаузи.

Застосування трансдермальних низькодозованих препаратів не підвищує ризику інсульту. Дані про безпеку, отримані у дослідженнях застосування низьких і наднизьких доз естрогенів і прогестагенів, викликають надію та свідчать про незначну кількість небажаних ефектів.

За результатами єдиного, належним чином спланованого клінічного дослідження за участю жінок у постменопаузі з наявністю в анамнезі ішемічного інсульту або транзиторної ішемічної атаки, терапію естрогенами не слід застосовувати для вторинної профілактики інсульту. 


\section{Вплив 3Гт на систему зсідання крові:}

- венозна тромбоемболія - одне з основних небажаних явищ на тлі застосування пероральної ЗГТ і селективних модуляторів естрогенових рецепторів;

- ризик серйозних венозних тромбоемболічних ускладнень, пов'язаний із застосуванням ЗТГ, підвищується з віком (хоча $\epsilon$ мінімальним для жінок групи низького ризику віком до 60 років), а також за наявності ожиріння та тромбофілії;

- ризик венозної тромбоемболії зростає зі збільшенням дози естрогену та $є$ вищим у перші роки терапіі;

- застосування $17 \beta$-естрадіолу (але не етинілестрадіолу) у різних лікарських формах, не призначених для перорального приймання (трансдермальні препарати), може мати переваги за наявності підвищеного ризику венозної тромбоемболії завдяки відсутності ефекту первинного проходження препарату крізь печінку;

- тип прогестагену може впливати на ризик розвитку тромбоемболії.

\section{Онкологічні ризики}

ЗГТ і рак молочної залози. Частота РМЗ у різних країнах варіює. Ступінь зв'язку між застосуванням ЗГТ у постменопаузі та розвитком РМ3 залишається суперечливим питанням.

Результати рандомізованого контрольованого дослідження WHI показали, що у групі із застосуванням естрогенів із прогестинами підвищувалася частота РМЗ у середньому після 5,6 року спостереження, проте після поправки на інші чинники ця величина виявилася статистично незначущою. Результати даного дослідження не виявили підвищення ризику розвитку РМЗ впродовж 5-7 років від початку лікування у пацієнток, які вперше вдалися до ЗГТ. Проте більшість учасниць цього дослідження мали надмірну масу тіла або ожиріння, що могло вплинути на вихідний рівень ризику розвитку РМЗ.

Наразі все ще бракує даних для оцінки можливої різниці у частоті РМЗ залежно від різних типів, доз і шляхів введення естрогенів, природного прогестерону, синтетичних прогестагенів або андрогенів. Тим не менше, за даними масштабних європейських спостережних досліджень можна припустити, що різниця у ризику для монотерапії естрогенами та комбінованої естроген-прогестагенної терапії відзначається лише у випадку використання певних категорій прогестагенів, а не похідних природного прогестерону.

Застосування мікронізованого прогестерону або дигідропрогестерону у поєднанні з пероральним або трансдермальним естрадіолом має ліпший профіль щодо ризику розвитку РМЗ порівняно із синтетичними прогестагенами щонайменше впродовж 5 років. Проте глибоких клінічних досліджень у цьому напрямку досі не проводилось.

Ризик розвитку РМЗ різко знижується після припинення 3Г, і через 5 років він може не перевищувати такий для жінок, які не застосовували ЗГТ. Цікаво, що одночасне різке скорочення застосування 3ГТ і незначне зниження частоти РM3, отримане за результатами дослідження WHI, у деяких пізніших дослідженнях розглядалося як доказ канцерогенних властивостей естрогенів. Натомість нещодавно отримані дані свідчать про підвищення частоти розвитку РМЗ на тлі стабілізації кількості пацієнток, які застосовують ЗГТ. Це дає підстави припустити, що ЗП скоріше може сприяти прогресуванню вже наявної пухлини молочної залози, ніж спричинювати розвиток раку.

Ймовірне підвищення ризику РМЗ внаслідок дії ЗГ є невеликим (менше від 0,1\% на рік, або менше від 1 випадку 1000 жінок за рік застосування) і меншим, ніж підвищений ризик РМ3, обумовлений відомими чинниками, такими як постменопаузне ожиріння, підвищене вживання алкоголю, знижена фізична активність.

До чинників, на які неможливо вплинути, належать родинний анамнез, підвищена мамографічна щільність грудей, атипова гіперплазія проток. Утім, слід пам'ятати, що підвищення щільності тканини залози на мамограмі внаслідок застосування комбінованої естроген-прогестагенної терапії може ускладнювати діагностичну інтерпретацію знімка.

Підвищений ризик РМЗ, що його відзначають на тлі застосування ЗП, можна дещо знизити шляхом добору терапії з меншим індивідуальним вихідним ризиком і надання інформації щодо профілактичних заходів, спрямованих на підтримання здорового способу життя.

\section{ЗГт і ендометрій:}

- монотерапія естрогенами супроводжується підвищенням ризику розвитку гіперплазії та раку ендометрію, який залежить від дози та тривалості терапії, і цей підвищений ризик зберігається впродовж багатьох років після припинення лікування;

- прогестагени запобігають проліферації ендометрію, спричиненій естрогенами, тому пацієнткам зі збереженою маткою слід додатково приймати прогестагени;

- для захисту ендометрію необхідно застосовувати прогестаген у відповідній дозі впродовж щонайменше 12 із 30 днів; 
- безперервний режим комбінованої терапії (естрогенами $з$ прогестагенами) асоціюється 3 нижчим ризиком розвитку гіперплазії та раку ендометрію порівняно з таким для популяції без лікування;

- нові режими (схеми) терапії із застосуванням низьких доз естрогенів і прогестагену спричинюють меншу стимуляцію ендометрію та менше кровотеч;

- низку переваг може мати внутрішньоматкове застосування препаратів;

- застосування ЗП зазвичай не рекомендується після лікування раку ендометрія, хоча даних наразі бракує;

- ожиріння підвищує ризик розвитку патології ендометрія.

ЗГт і рак яєчників. Дослідження WHI - єдине рандомізоване клінічне дослідження, у якому вивчали ризик розвитку раку яєчників на тлі ЗГТ. У жінок, які отримували комбіновану ЗГТ, не спостерігалося значного підвищення цього ризику. У цілому тривала монотерапія естрогенами може бути пов'язаною з незначним відносним ризиком розвитку раку яєчників, що складає 0,7 випадку на 1000 жінок за 5 років застосування, у той час як на тлі застосування комбінації естроген+прогестаген ризик $\epsilon$ значно нижчим або взагалі відсутній.

зГт і колоректальний рак. Результати більшості проведених обсерваційних досліджень показали зниження ризику розвитку колоректального раку у жінок на тлі застосування лише пероральної ЗГТ (як монотерапії естрогенами, так і у комбінації з прогестагенами). Застосування ЗГТ зберігає сприятливий ефект впродовж 4 років після припинення терапії.

ЗГт і рак шийки матки. Тривалі когортні дослідження показали відсутність підвищеного ризику розвитку раку шийки матки на тлі ЗГ. У дослідженні WHI на тлі ЗГТ підвищення ризику цієї патології також не відзначено.

урогінекологія. Такі симптоми, як сухість і болючість піхви, диспареунія, часті сечовиділення та/або позиви до сечовипускання, ніктурія, $\epsilon$ надто розповсюдженими у жінок у постменопаузі. Розповсюдженість нетримання сечі 3 віком збільшується. У цілому 25\% жінок скаржаться на нетримання сечі, з них 7\% вважають його значним. Половина жінок скаржаться не нетримання сечі під час стресу, 11\% - на імперативне нетримання та $36 \%$ - на змішане.

Основні лікувальні рекомендації

- Естрогени не справляють швидкого та суттєвого сприятливого ефекту на частоту сечовипускання та випадків нетримання сечі. Часто необхідною є тривала терапія, оскільки симптоми можуть відновлюватися після припинення лікування. Системних ризиків на тлі місцевого застосування естрогенів із низьким потенціалом і в низьких дозах не визначено.

- Для жінок у постменопаузі 3 гіперактивністю сечового міхура після зміни способу життя та ретренінгу сечового міхура терапією першої лінії $\epsilon$ антимускаринові препарати у поєднанні 3 місцевим застосуванням естрогенів.

- Для всіх жінок, які скаржаться на стресове нетримання сечі, насамперед буде корисним тренування м'язів тазового дна. Антидепресант дулоксетин може синергічно діяти з консервативною терапією. Проте багато жінок потребують хірургічного лікування, і найчастіше з цією метою застосовуються ретролобкова та трансобтураторна петлі.

- Жінкам зі стресовим нетриманням сечі системна терапія естрогенами не рекомендується.

- Тиболон сприяє підвищенню статевого потягу та активності.

Постменопаузна вагінальна атрофія. Вагінальна атрофія стає клінічно вираженою через 4-5 років по настанню менопаузи, і об'єктивні зміни, як і суб'єктивні скарги, відзначаються у 25-50\% усіх жінок у постменопаузі. Слід щонайранніше виявляти постменопаузну вагінальну атрофію та призначати відповідне лікування на ранній стадії, перед формуванням необоротних змін. Лікування потрібно продовжувати для збереження позитивного ефекту. Системна 3Г та естрогени для місцевого застосування мають здатність перетворювати атрофічні зміни сечостатевої системи, обумовлені недостатністю естрогенів, і підтримувати слизову піхви у відповідному до віку здоровому стані.

У дослідженнях пероральних та інтравагінальних форм естрогенів встановлено позитивний вплив саме останніх щодо сухості піхви та диспареунії. Ефективними $\epsilon$ усі препарати для місцевого застосування, і вибір методу лікування звичайно залежить від уподобань пацієнтки. За наявності вагінальних симптомів у зменшенні сухості піхви, вираженості диспареунії, ознак атрофії слизової, у поліпшенні індексу дозрівання слизової та зниженні рН подібну ефективність проявляють вагінальне кільце з естрадіолом, естрадіол у таблетках і вагінальний крем із кон'югованим естрогеном.

Дані щодо застосування вагінальних естрогенів у жінок із гінекологічними видами гормонозалеж- 
ного раку обмежено, а отже, у їх застосуванні слід проявляти обережність.

У цілому ЗГТ залишається найефективнішим засобом за наявності вазомоторних симптомів і атрофії органів сечостатевої системи. ЗГТ може позитивно впливати й на інші обумовлені менопаузою порушення, такі як біль у суглобах і м'язах, перепади настрою, порушення сну, статева дисфункція (у т.ч. зниження лібідо). Також відзначено її позитивний вплив на якість життя.

\section{ВИСНОВКИ}

ЗГТ у постменопаузі $\epsilon$ частиною загальної стратегії ведення цієї категорії пацієнток. Необхідно обов'язково оцінювати користь і ризики її застосування, що можуть значно різнитися у кожному окремому випадку. Важливо, що проведені останніми десятиріччями дослідження допомогли встановити, що ризики можна звести до мінімуму, а користь - до максимуму, обравши оптимальну схему лікування в оптимальний час.

Безпечність ЗГТ значною мірою залежить від віку. Здорові жінки віком до 60 років не мають надто турбуватися про профіль безпеки ЗГТ. Результати нещодавніх досліджень і повторний аналіз результатів минулих досліджень із урахуванням віку пацієнток показали, що у більшості випадків потенційні сприятливі ефекти ЗГ є численними, а ризики, навпаки, незначними, якщо терапію розпочато протягом кількох років після початку менопаузи.

Щодо тривалості застосування 3ГТ, то жінки можуть отримувати їі доти, доки вона справляє сприятливий вплив на симптоми. Причому пацієнтки мають бути поінформованими про ризики, пов'язані з їх схемою лікування, та ризики, пов'язані 3 типовими обставинами. Вони можуть намагатися припинити лікування кожні декілька років, але у деяких жінок симптоми менопаузи тривають багато років, і цих жінок необхідно лікувати найменшими дозами препаратів.

\section{ЛІТЕРАТУРА}

1. Подзолкова Н.М. Гормональная контрацепция: вопросы безопасности и переносимости // РМЖ. - Специальный номер. Мать и дитя. Акушерство и гинекология. Педиатрия. - 2009. - № 1. - C. 5-10.

2. Татарчук Т.Ф., Ефименко О.А., Исламова А.О. Менопауза: новый взгляд на старую проблему // Репродуктивная эндокринология. - 2013. - № 1(9). C. 7-12.

3. Татарчук Т.Ф., Ефименко О.А. Современный взгляд на заместительную гормональную терапию //
Репродуктивная эндокринология. - 2012. - № 2(4). C. 34-38.

4. Gold E.B., Lasley B., Crawford S.L. et al. Relation of Daily Urinary Hormone Patterns to Vasomotor Symptoms in a Racially/Ethnically Diverse Sample of Midlife Women: Study of Women's Health Across the Nation // Reproductive Sciences. - 2007. - Vol. 14(8). P. 786-797.

5. Grodstein F., Stampfer M.J., Manson J.E. et al. Post menopausal estrogen and progestin use and the risk of cardiovascular disease // New England Journal of Medicine. - 1996. - Vol. 335. - P. 453-461.

6. Harlow S.D., Gass M., Hall J.E. et al. Executive summary of the Stages of Reproductive Aging Workshop + 10: addressing the unfinished agenda of staging reproductive aging // J. Clin. Endocrinol. Metab. - 2012. - Vol. 97 (4). - P. 1159-1168.

7. Nelson D.B., Sammel M.D., Freeman E.W. et al. Predicting participation in prospective studies of ovarian aging // Menopause. - 2004. - Vol. 11(5). - P. 543-548.

8. Nelson H.D. Menopause // Lancet. - 2008. - Vol. 371. P. 760-770 [пер. с англ. яз. по: Therapia. - 2008. Vol. 5 (26). - C. 9-20].

9. Smeets-Goevaers C.G., Lesusink G.L., Papapoulos S.E. et al. The prevalence of low bone mineral density in Dutch perimenopausal women: the Eindhoven perimenopausal osteoporosis study // Osteoporos Int. - 1998. - Vol. 8 (5). - P. 404-409.

10. Sturdee D.W., Pines A. Update IMS recommendations on postmenopausal hormone therapy and preventive strategies for medlife health // Climacteric. - 2011. Vol. 14. - P. 302-320.

11. Randolph J.F.Jr., Zheng H., Sowers M.F.R. et al. Change in Follicle-Stimulating Hormone and Estradiol Across the Menopausal Transition: Effect of Age at the Final Menstrual Period // J. Clin. Endocrinol. Metab. - 2011. - Vol. 96 (3). - P. 746-754.

\section{PEЗЮME}

Менопауза: современные представления о безопасности и эффективности лечения

\section{М.Л. Кирилюк}

В лекции представлены данные о патогенезе, клинике и современном лечении менопаузного синдрома. Рассмотрены вопросы безопасности заместительной гормональной терапии.

ключевые слова: менопауза, лечение.

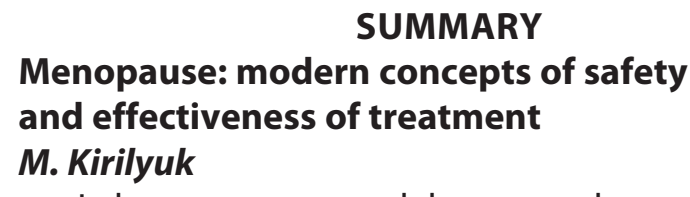

In lectures presented data on pathogenesis, clinical manifestations and current treatment of menopausal syndrome. Questions of safety of hormone replacement therapy are being discussed.

Key words: menopause, treatment.

Дата надходження до редакиії 15.12.2013 p. 